\title{
Evaluation of the Anti-Poaching Programme of the Cross River National Park Okwango Division, Nigeria 2002 to 2013
}

\author{
Augustine Ugar Ogogo', Sijah Agbor Asuk ${ }^{1}$, Rebecca Victor Ikpeme ${ }^{2}$ \\ ${ }^{1}$ Department of Forestry and Wildlife Resources Management, University of Calabar, Calabar, Nigeria \\ ${ }^{2}$ Cross River National Park Headquarters, Akamkpa, Nigeria \\ Email: auogogo@yahoo.com
}

Received 19 July 2014; revised 2 September 2014; accepted 21 September 2014

Copyright (C) 2014 by authors and Scientific Research Publishing Inc.

This work is licensed under the Creative Commons Attribution International License (CC BY). http://creativecommons.org/licenses/by/4.0/

(c) (i) Open Access

\begin{abstract}
Poaching of wildlife has continued to be the major problem confronting national parks managers in Nigeria in spite of effort being made to curb the ugly trend. This paper examined the antipoaching programme of the Cross River National Park Okwango Division Nigeria from 2002 to 2013, with a view to making recommendations for the improvement of the programme. Focused group discussions, personal interviews, review of official records and structured questionnaires were used to collect data. Analysis of variance using randomized complete block design and student's t-test were used to analyse data. Result showed that 1 - 5 arrests of poachers per month per patrol station was significantly $(P<0.05)$ higher than 6 arrests and above. On the other hand, the number of hunters' sheds and traps destroyed had 21 and above being significantly $(P<0.05)$ higher than 20 and below. There was no significant difference $(P>0.05)$ in the number of poachers arrested and fined between 2002 to 2006 and 2007 to 2011. The low performance of the anti-poaching programme was attributed to poorly equipped rangers' posts as well as well the absence of alternative livelihood options in the enclave and surrounding communities. It was recommended that more rangers should be employed, and the rangers should be adequately kitted, well equipped patrol stations be constructed and the enclave and surrounding communities be involved in the management of the National Park in addition to providing them with alternative livelihood options.
\end{abstract}

\section{Keywords}

Evaluation, Anti-Poaching, Cross River National Park, Okwango, Nigeria 


\section{Introduction}

Nigerian National parks are bedeviled with a myriad of problems prominent among them being poaching, logging, illegal grazing and bush burning. Illegal hunting of animals for trophy and meat is usually a major problem experienced in protected areas and is more or less universal in conservation areas of Africa (Bell, 1984). Wildlife is facing serious challenges all over the world, and many fauna and flora species are continuously driven closer to extinction on a daily basis (Ijeomah et al. 2013). According to Goodall (2011), Poaching and illegal trade in wildlife has become an organized, lucrative and a capital intensive business, with trafficking routes extending from remote national parks and reserves, where animals are trapped and killed, to major urban centres where they are sold and consumed.

Although wildlife laws exist as a global conservation tool for protection of species, most remain unenforced, due to limited human, financial and material resources required to monitor illegal activities and enforce existing laws. Rules and measures to enforce them are at the heart of conservation. Wildlife acts by themselves cannot deal with all known anthropogenic threats. Complementary actions are therefore needed to back up legislation. Newmark et al. (1993) stated that it is likely that the three crucial factors in mitigating the effects of conflict on biodiversity are the continuous on-the-ground patrol by well trained field staff, continuous law enforcement and secured funding.

This work involved assessment of available personnel and equipment for anti-poaching patrols, evaluation of the level of success of patrol operations and identification of the challenges militating against effective antipoaching activities in the studied area and recommendations for the improvement of ant-poaching programmes in the studied area.

\section{Materials and Methods}

\subsection{The Study Area}

Okwango Division is one of the two divisions that make up the Cross River National Park which was established in 1991 along with six others. The division operates as a single range (Okwango Range) and boarders Takamanda National Park in the Republic of Cameroon.

It is located between latitude $6^{\circ} 17^{\prime \prime} \mathrm{N}$ and $6.28^{\circ} 33^{\prime \prime} \mathrm{N}$ of the Equator and longitudes $9^{\circ} 14^{\prime \prime} \mathrm{E}$ and $9.23^{\circ} 33^{\prime \prime} \mathrm{E}$ of the Greenwich Meridian. It has an area of about $1000 \mathrm{Km}^{2}$ and an altitude of $1500-1700 \mathrm{~m}$ above sea level. It is separated from the Oban Division to the south by about $50 \mathrm{~km}$ of disturbed rainforest (Global Tree Planters 2011). The study area cuts across two local Government areas namely, Boki and Obanliku.

\subsection{Methods of Data Collection}

Method of data collection included personal interview of key officers of the Cross River National Park, Focused Group Discussion and survey using questionnaires. Two sets of structured questionnaires were used. Stratified random and purposive sampling methods were used to distribute questionnaires. Forty (40) questionnaires were equitably distributed (5 each) to park rangers in the eight (8) patrol stations in the division. At the time of this study only 5 patrol rangers were deployed to each patrol station, thus a $100 \%$ survey was carried out by administering questionnaires to all rangers present in the 8 stations.

Secondary data on equipment available in the Division such as Motor cycles, guns, ammunition headlamps, GPS, Camping tents, reports on arrests and prosecution of poachers, rangers' allowances, and uniforms was collected from documented information at the Park Headquarters.

\subsection{Data Analysis}

The data collected from the questionnaires were subjected to Randomized complete block design and student's t-test analyses.

\section{Result}

The results are presented in the tables below.

The result showed that 1 - 5 poachers had a significantly $(P<0.05)$ higher frequency in the number arrested monthly in all the stations followed by 6 - 10 while 11 and above had the least. Total number of poachers ar- 
rested under categories 6 - 10 and 11 and above were not significantly $(P>0.05)$ different from each other. There was no significant difference $(P>0.05)$ between the eight patrol stations in the number of poachers arrested monthly (See Table 1).

The number of hunters' sheds destroyed at the different stations is given in Table 2. The category with 21 sheds and above had a significantly $(P<0.05)$ highest frequency with a mean of 2.75 followed by $11-20$ sheds while the one with 1 - 10 sheds had the least. Again, there was no significant difference $(P>0.05)$ between the patrol stations in the number of hunters' sheds destroyed.

The number of traps removed by rangers at the different patrol stations is given in Table 3 . The category of 21 and above traps had the highest frequency with a mean of 3 which was significantly $(P<0.05)$ higher than the other two categories $(1-10$ and 11 - 20) which were not significantly $(P>0.05)$ different from each other. Again, the different patrol stations showed no significant $(P>0.05)$ difference between each other in the number of traps removed.

The Number of poachers arrested and fined from 2002 to 2011 is shown in Table 4.

The t-test analysis at 0.05 with 6 degrees of freedom revealed that there was no significant difference $(P>$ 0.05) between the numbers of poachers arrested and fined between 2002 and 2011.

\section{Discussion}

From the result, the number of poachers arrested was far fewer than the number of poachers' sheds destroyed and the traps removed. This could be due to the fact that the poachers are more difficult to catch. They are highly mobile and flee the scene as soon as they sense that the rangers are approaching unlike their sheds and traps that are static and cannot easily be dismantled. Thus the actual number of poachers operating in the national park could be much higher than the number arrested. Another reason could be that the poachers have informants that

Table 1. Distribution of poachers arrested at each station monthly.

\begin{tabular}{cccccc}
\hline Patrol station & $1-5$ & $6-10$ & 11 \& above & Total & Mean \\
\hline Abo-Obisu & 3 & 2 & 0 & 5 & 1.7 \\
Anape & 4 & 1 & 0 & 5 & 1.7 \\
Bamba & 3 & 2 & 0 & 5 & 1.7 \\
Bashu & 2 & 3 & 0 & 5 & 1.7 \\
Buabre & 4 & 1 & 0 & 5 & 1.7 \\
Butatong & 3 & 0 & 0 & 5 & 1.7 \\
Mbuli & 2 & 3 & 0 & 5 & 1.7 \\
Okwangwo & 3 & 2 & 0 & 40 & 1.7 \\
Total & 24 & 14 & 2 & & \\
Mean & $3^{\mathrm{a}}$ & $1.75^{\mathrm{b}}$ & $0.25^{\mathrm{c}}$ & & \\
\hline
\end{tabular}

Note: Mean values on the same row with different superscripts were significantly different $(P<0.05)$.

Table 2. Distribution of number of hunters' sheds destroyed at each patrol station monthly.

\begin{tabular}{cccccc}
\hline & \multicolumn{5}{c}{ No. of sheds destroyed } \\
\hline Patrol station & $1-10$ & $11-20$ & 21 \& above & Total & Mean \\
\hline Abo-Obisu & 1 & 1 & 3 & 5 & 1.7 \\
Anape & 0 & 2 & 3 & 5 & 1.7 \\
Bamba & 1 & 2 & 2 & 5 & 1.7 \\
Bashu & 0 & 2 & 3 & 5 & 1.7 \\
Buabre & 0 & 1 & 3 & 5 & 1.7 \\
Butatong & 1 & 1 & 3 & 5 & 1.7 \\
Mbuli & 0 & 2 & 1 & 5 & 1.7 \\
Okwangwo & 2 & 2 & $2.75^{\mathrm{a}}$ & & 5 \\
Mean & $0.63^{\mathrm{c}}$ & $1.63^{\mathrm{b}}$ & & 5 & \\
\hline
\end{tabular}

Note: Mean values on the same row with different superscripts were significantly different $(P<0.05)$. 
Table 3. Distribution of traps removed.

\begin{tabular}{|c|c|c|c|c|c|}
\hline \multicolumn{6}{|c|}{ No. of Traps removed } \\
\hline Patrol station & $1-10$ & $11-20$ & $21 \&$ above & Total & Mean \\
\hline Abo-Obisu & 1 & 2 & 2 & 5 & 1.7 \\
\hline Anape & 0 & 1 & 4 & 5 & 1.7 \\
\hline Bamba & 0 & 0 & 5 & 5 & 1.7 \\
\hline Bashu & 1 & 2 & 2 & 5 & 1.7 \\
\hline Buabre & 0 & 3 & 2 & 5 & 1.7 \\
\hline Butatong & 1 & 1 & 3 & 5 & 1.7 \\
\hline Mbuli & 0 & 1 & 4 & 5 & 1.7 \\
\hline Okwangwo & 1 & 2 & 1 & 5 & 1.7 \\
\hline Total & 4 & 12 & 24 & 40 & \\
\hline Mean & $0.5^{\mathrm{b}}$ & $1.5^{\mathrm{b}}$ & $3^{\mathrm{a}}$ & & \\
\hline
\end{tabular}

Note: Mean values on the same row with different superscripts were significantly different $(P<0.05)$.

Table 4. Number of poachers fined between 2002 and 2011.

\begin{tabular}{cccc}
\hline & & Years & $2007-2011$ \\
\hline Offences & $2002-2006$ & 27 \\
\hline Logging & 32 & 27 \\
Hunting & 29 & 5 & 7 \\
Water poisoning & 5 & 66 & 16.50 \\
Grazing & 11 & 77 & 19.25 \\
Total & & 19 & \\
\hline
\end{tabular}

notify them in advance when the rangers are going on patrol. They then keep away from the National park during the period to avoid being caught.

From personal interview of rangers, it was observed that there was no rangers' camp at Okwango and Okwa which are enclave communities in the Cross River National Park Okwango Division. Rangers sometimes stay with friends and relatives in the enclaves when they are going on patrol or when returning from patrols. There was an incident when a poacher was arrested in the National Park by rangers, in the process of taking him out for prosecution; the rangers had to pass the night at Okwango. The youth of the community got to know of the incident. They mobilized and forcefully released the poacher. This scenario could explain why the number of poachers arrested from 2002 to 2006 and 2007 to 2011 did not differ significantly ( $P>0.05$, t-test). This is in line with the observations of Goodall, (2011) who stated that Poaching and illegal trade in wildlife has become an organized, lucrative and a capital intensive business, with trafficking routes extending from remote national parks and reserves, where animals are trapped and killed, to major urban centres where they are sold and consumed. Robinson and Bennett (2000) also observed that the high economic value attached to the business of hunting and the increasing commercialization of hunting are critical factors driving overexploitation and unsustainable use of wild meat. Okwango Division of the Cross River National park harbours the rare Cross River gorilla (Gorilla gorilla diehli), drill monkeys (Mandrillus leucopheus), forest elephants (Loxodonta africana cyclotis) and chimpanzees (Pan troglodytes) (Global Tree Planters Limited 2011) from which highly prized trophies in the international market are obtained.

Another factor is that wild meat is a significant source of easily accessible animal protein for landless, rural peoples throughout Asia, Africa and Latin America (Conservation Biology, 2002).

The threat of local and global species extinctions and associated declines in wild meat supplies for local communities are therefore concerns shared by those engaged in the conservation of biodiversity and those pursuing the betterment of human lives. Local and ecological extinctions remain undetected until they become the focus of investigations by which time it is often too late.

The low impact from the number of hunters arrested and hunters' sheds destroyed in each station in the study area may have been due to the lack of adequate on the-ground field staff to patrol and monitor the area. The high 
presence of poachers as evidenced from their activities which include hunters' sheds and traps could be due to insufficient incentives for residents to stop poaching in the area (Gibson and Marks, 1995; Bekenov et al., 1998; Newmark et al., 1993). Jacob and Ogogo (2011) reported that 74\% of the people living around the Cross River National park claim not to be involved in the management of the park. This could account for the high cases of poaching observed in the park. The findings agree with the views expressed by Nchor (1996) who stated that the Cross River National Park continues to face the threat of poaching.

\section{Conclusions and Recommendations}

\subsection{Conclusions}

Poaching is a complex phenomenon and its motivation and impact on wildlife are diversified in different countries.

The anti-poaching programme in Okwangwo division has very little effect on curbing poaching activities in the area. This is basically due to two factors: limited number of patrol staff to enforce the law enforcement and lack of alternative livelihood options for the hunters.

\subsection{Recommendations}

Thus, the anti-poaching programme should be beefed up with adequate number of well trained staff, equipped with adequate kits. Also more stringent penalties should be given to arrested poachers to discourage others from engaging in the activity.

Alternative sources of protein and income like snail farming, bee keeping and mushroom growing should be introduced in the enclave and surrounding communities in the National Park.

\section{References}

Bekenov, A. B., Grachev, Iu. A., \& Milner-Gulland, E. J. (1998). The Ecology and Management of the Saiga Antelope in Kazakhstan. Mammal Review, 28, 1-52. http://dx.doi.org/10.1046/j.1365-2907.1998.281024.x

Bell, R. H. V. (1984). Monitoring Illegal Activity and Law Enforcement in African Conservation Areas. In T. Holmen, J. Muya, \& E. Roskaft (Eds.), Local Law Enforcement and Illegal Bushmeat Hunting Outside Serengeti National Park, Tanzania, Conservation Biology (pp. 449-465). Cambridge: Cambridge University Press.

Conservation Biology (2002). Wild-Meat Use, Food Security, Livelihoods and Conservation. Conservation Biology, 16, 580583. http://dx.doi.org/10.1046/j.1523-1739.2002.01634.x

Gibson, C. C., \& Marks, S. A. (1995). Transforming Rural Hunters into Conservationists: An Assessment of CommunityBased Wildlife Management Programs in Africa. World Development, 23, 941.

http://dx.doi.org/10.1016/0305-750X(95)00025-8

Global Tree Planters Limited (2011). Participatory Management Plan of Cross River National Park 2011-2015.

Goodall, J. (2011). www.janegoodall.org

Ijeomah, H. M., Ogogo, A. U., \& Ogbara, D. (2013). Analysis of Poaching Activities in Kainji Lake National Park of Nigeria. Environment and Natural Resource Research, 3, 51-61.

Jacob, D. E., \& Ogogo, A. U. (2011). Community Participation in Protected Area Management: A Case Study of Cross River National Park. Proceedings of the 34th Annual Conference of the Forestry Association of Nigeria, Osogbo, 5-10 December 2011, 412-417.

Nchor, A. A. (1996). Integrating Local Communities in the Management of Cross River National Park. In E. Obot, \& J. Barker (Eds.), Essential Partnership, the Forest and the People. Proceedings of Workshop on the Rainforest of South Eastern Nigeria and South Western Cameroon (pp. 135-140), Obanliku, 20-20 October 1996.

Newmark, W. D., Foley, C. A. H., Erfimshaw, J. M., Chanbegga, D. R., \& Rutazaa, A. G. (1993). Local Extinction of Large Mammals within Increasing Isolation and Forest Conservation. In W. D. Newmark (Ed.), The Conservation of Mount Kilimanjaro (pp. 25-46). IUCN, Gland. 
Scientific Research Publishing (SCIRP) is one of the largest Open Access journal publishers. It is currently publishing more than 200 open access, online, peer-reviewed journals covering a wide range of academic disciplines. SCIRP serves the worldwide academic communities and contributes to the progress and application of science with its publication.

Other selected journals from SCIRP are listed as below. Submit your manuscript to us via either submit@scirp.org or Online Submission Portal.
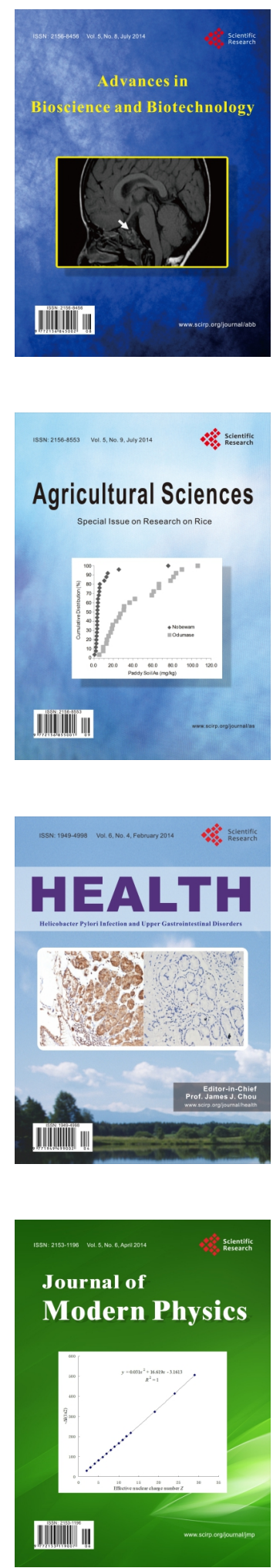
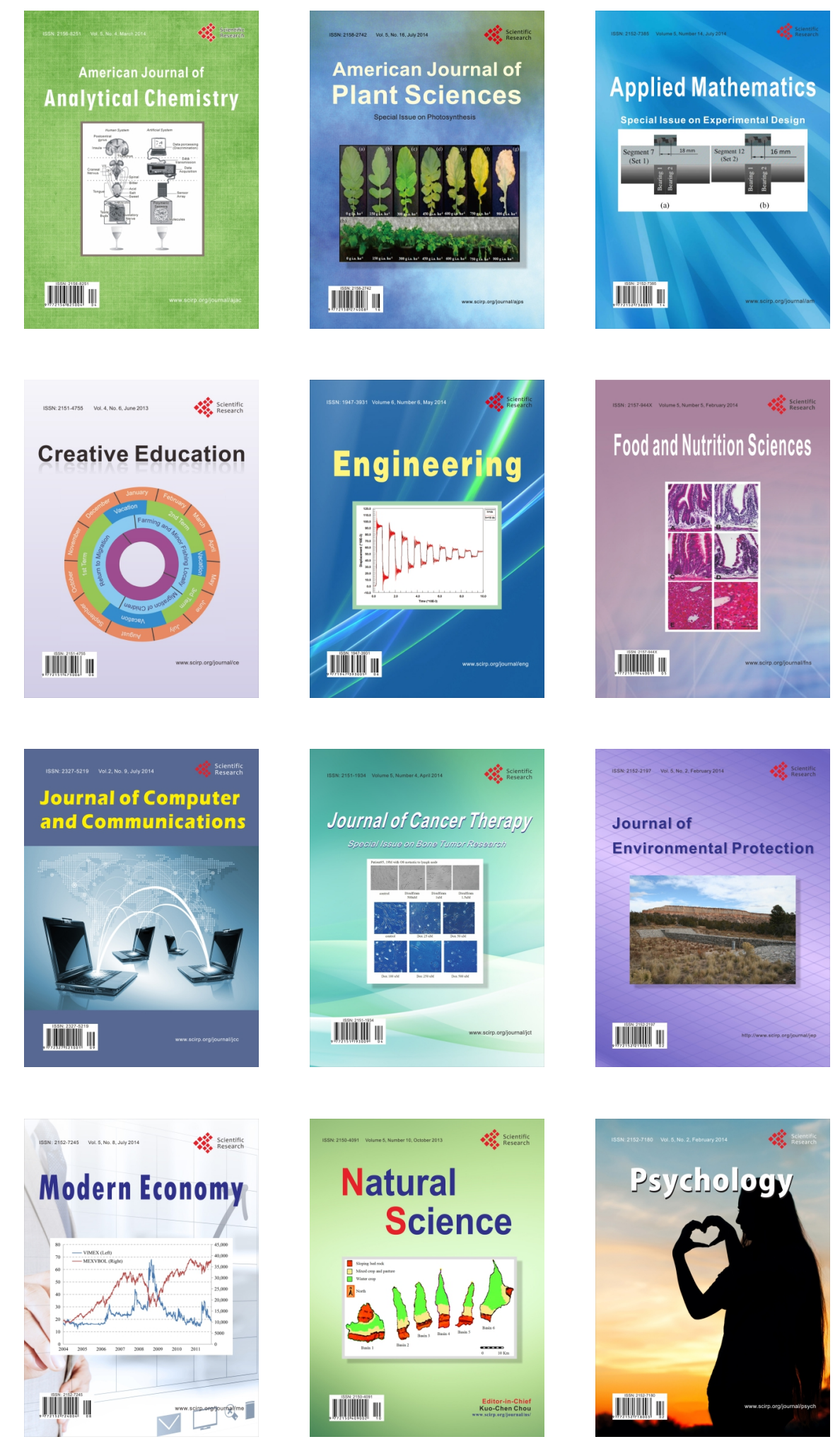